\title{
Medicinal plants utilized for hepatic disorders in Ethiopian traditional medical practices: a review
}

\author{
Abrham Belachew Muluye ${ }^{1 *}$ and anduken Wubetu Ayicheh²
}

\begin{abstract}
Background: Ethiopia is among the top floral biodiversity rich countries in the world. More than 7000 species of plants, $15 \%$ of they are endemic, are reported in the country. Accessibility, cultural enrichment, and cheapness make $80 \%$ of the Ethiopian people used indigenous plants for various health ailments and diseases in their traditional medical practices. Therefore, the current review examined the use patterns of medicinal plants utilized for hepatic disorders in Ethiopian traditional medical practices for further scientific investigations.
\end{abstract}

Methods: Ethnobotanical and related studies on medicinal plants utilized for hepatic disorders in Ethiopia were reviewed. Ethiopian university websites, Google, Google Scholar, PubMed, Medline, and other online internet search engines were used to access literature articles. The number of plant species and families, used parts, used conditions, modes of preparation, and routes of administration were tabulated and summarized using Excel spreadsheet and descriptive statistics, respectively.

Results: The current review showed that 276 plant species belonging to 89 families were used for hepatic disorders in Ethiopian traditional medical practices. The commonly utilized plant families were Asteraceae (10.14\%), Fabaceae (9.08\%), Euphorbiaceae (7.61\%), Laminaceae (4.35\%), Solanaceae (3.99\%), and Aloaceae (2.90\%). Justicia schimperiana (34.34\%), Croton macrostachyus, and Phytolacca dodecandra (each 20.20\%), Cordia africana, Cucumis ficifolius, and Rumex abyssinica (each 10.10\%) were among the most utilized plant species. They were mainly distributed in Oromo (58\%), southern (36\%), and Amhara (35.5\%) regions. Herbs (47.10\%), shrubs (26.09\%) and trees (20.65\%) were their primary growth forms, while leaves (34.30\%) and roots (33.06\%) were their commonly utilized parts. Pounding (24.59\%), decoction (19.67\%), powdering (9.84\%), and concoction (9.13\%) were their major modes of preparations. Water was the most utilized solvent (48.26\%) for the remedy preparations, which were mainly administered orally (76.35\%).

Conclusions: This review showed that many claimed medicinal plants were utilized for the treatment of hepatic disorders in Ethiopian traditional medical practices. Hence, further experimental investigation is recommended to standardize their quality and phytochemistry and validate their safety and efficacy. Documentation and conservation of indigenous herbal knowledge have also been strengthened.

Keywords: Ethnobotany, Ethiopia, Folklore, Hepatic disorders, Herbalism, Medicinal plants, Traditional medicine

\footnotetext{
* Correspondence: abrhambel@gmail.com

'Department of Pharmacy, College of Medicine and Health Sciences, Bahir

Dar University, Bahir Dar, Ethiopia

Full list of author information is available at the end of the article
}

\section{Springer Open}

(c) The Author(s). 2020 Open Access This article is licensed under a Creative Commons Attribution 4.0 International License, which permits use, sharing, adaptation, distribution and reproduction in any medium or format, as long as you give appropriate credit to the original author(s) and the source, provide a link to the Creative Commons licence, and indicate if changes were made. The images or other third party material in this article are included in the article's Creative Commons licence, unless indicated otherwise in a credit line to the material. If material is not included in the article's Creative Commons licence and your intended use is not permitted by statutory regulation or exceeds the permitted use, you will need to obtain permission directly from the copyright holder. To view a copy of this licence, visit http://creativecommons.org/licenses/by/4.0/. 


\section{Introduction}

The liver is one of the largest and most prominent organs in the body. It is a critical center for diverse physiological processes, including macronutrient metabolism, blood volume regulation, immune system support, endocrine control of growth signaling pathways, lipid homeostasis, and detoxification of xenobiotics, including drugs [1]. Its structure and function are, however, damaged by different disease states. The incidence of hepatic diseases has increased worldwide because of changes in lifestyle and dietary habits, contamination in food or drinking, chemical and drug abuse, and hepatic infections. The most important hepatic diseases include hepatitis, cirrhosis, fatty liver, bile duct obstruction, and jaundice. They are the major cause of morbidity and mortality globally [1-4].

Managements of hepatic disorders are continuously challenged due to the unavailability of effective drugs that target, arrest, or reverse disease progression, their adverse effects, and their costs, especially in the developing world [5-7]. Plant-derived compounds from indigenous cultural practices are an effective alternative for the sources of new hepatoprotective remedies $[3,8]$. Scientific findings have shown that phytochemicals with antioxidant, anti-inflammatory, and antiviral properties are effective hepatoprotective agents [9].

Human beings use plants for the treatment of different ailments, including hepatic disorders, since ancient times [10]. Approximately $14 \%$ to $28 \%$ of higher plant species worldwide are used medicinally for some sort of ailments and diseases in the world [11, 12]. Approximately $80 \%$ of the world's population, especially in the developing world, utilized plant-derived drugs for primary healthcare demands. Nearly $50 \%$ of modern drugs are based on natural products [13-15]. Because of gaining in their popularity and importance, traditional medical practitioners are now given great attention in developed countries as well [16]. Only about one-tenth of the flowering plant species occurring globally are investigated for their pharmaceutical potential [17]. However, most of these plants have not been explored chemically and pharmacologically [18]. Nearly 45,000 plant species are estimated in Africa, but only $11 \%$ of them have documented medicinal use [19]. Medicinal plants have been shown to be effective for the correction of different hepatic ailments [20]. Hence, nature provides a right solution for every ailment, including hepatic disorders, in the form of such plants [17].

Because of cultural entrenchment, accessibility, and affordability, nearly $80 \%$ of the Ethiopian population depends on traditional indigenous medicine as a primary source of healthcare. The practice is mostly implemented using herbs, spiritual healing, bone-setting, and minor surgical procedures. The practice is vastly complex and diverse among different ethnic groups [21, 22]. More than $95 \%$ of traditional Ethiopian medicinal preparations are made from plant origin. Ethiopia is considered one of the richest genetic resource centers in the world in terms of plant diversity. Approximately over 7000 higher plant species distributed in about 245 families are found in the country that make the sixth and twelfth plant biodiversity rich countries in Africa and the world, respectively. Approximately $15 \%$ of these plants are endemic to the country, with their healing potential that makes the country one in six countries in the world. In addition, Ethiopia has a wide range of climates, cultures, and diversified populations [23, 24].

Indigenous cultural practices on medicinal plants are inconsistently documented throughout the world, especially in developing one including Ethiopia [25]. Medicinal plants, both endemic and widespread, their resources and knowledge about their usage must be preserved because these plants could be a renewable source for new drugs [26] and for the benefit of humankind in general [27], before they lose forever due to environmental and anthropogenic factors [28-30]. Consistent documentation of ethnobotanical and ethnopharmacological information on indigenous knowledge of medicinal plants is, therefore, a vehicle for preserving cultural heritage, ethnopharmacological bases of drug research, and preservation of biological diversity [27, 31]. This is also vital for smooth and consistent investigations on their safety, efficacy, and quality [32-34]. Therefore, the aim of the current review was to prepare a compiled checklist of medicinal plants used traditionally for the management of hepatic disorders from various ethnobotanical, ethnopharmacological, and related studies in Ethiopia.

\section{Methods \\ Search strategy}

A website-based search strategy was employed in research literature articles related to medicinal plants used traditionally for the treatment of hepatic disorders in Ethiopia. Google search engines and local university research repository websites were used to access and collect unpublished research reports (MSc theses and $\mathrm{PhD}$ dissertations), while published journal articles were searched and accessed using global scientific databases including Google Scholar, Medline, PubMed, Scopus, Web of Science, and related online internet search engines. The resource materials were collected between June and August 2017. A literature search was done using keywords consisting of traditional medicine, ethnobotany, ethnomedicine, ethnopharmacology, phytopharmacology, phytomedicine, hepatoprotective plants, and Ethiopia, accompanied by liver diseases, liver 
ailments, hepatic disorders, liver problems, hepatitis, jaundice, hepatic cirrhosis, and liver infections.

\section{Selection criteria}

Both published and unpublished ethnobotanical, ethnopharmacological, and ethnomedicinal surveys reporting on the use of plants for hepatic disorders and conducted at any time in Ethiopia were included in the review, while plants from review, non-open accessed and abstract-only articles, historical documents, and experimental studies as well as plants of unknown locations and scientific names were excluded from the review. Availability of plants was also checked and confirmed using various volumes (1-8) of the Flora of Ethiopia and Eritrea. In addition, missing information in some studies, particularly local names and habit of the plants, and misspelled scientific names were retrieved from the Natural Database for Africa and Google search engines.

\section{Data extraction}

Valuable information on medicinal plants, including species and family of the plants, their specific uses, parts used, conditions and modes of preparation, routes of administration, and their regional distribution were thoroughly explored, extracted, and tabulated using an excel spread sheet. The collected data were analyzed using descriptive statistics to evaluate the frequency and percentage of different aspects.

\section{Results}

\section{Diversity of medicinal plants}

Indigenous knowledge pertaining to plant distribution, management, and traditional medicinal use requires standard procedures for botanical identification, reliable documentation, and further preservation. The current review included a total of 100 original ethnomedicinal studies ( 74 were journal articles while others were theses and dissertations). A total of 276 medicinal plants from 89 families were used traditionally for the treatment of different hepatic disorders in Ethiopia. Further information for each plant species is provided in Additional file 1. They were mainly categorized under Asteraceae (10.14\%), Fabaceae (9.08\%), Euphorbiaceae (7.61\%), Laminaceae (4.35\%), Solanaceae (3.99\%), Aloaceae (2.90\%), and Rubiaceae (2.17\%) families, as shown in Fig. 1.

Many medicinal plant species $(n=160)$ have been reported from the Oromia region [35-68] followed by southern nations, nationalities, and people $(n=100)$ [69-83], Amhara $(n=98)$ [84-105], Tigray $(n=52)$ [106-116], Afar $(n=19)[117,118]$, Addis Ababa $(n=$ 11) $[119-121]$, Dire Dawa $(n=10)[122,123]$, Harari $(n=7)$ [124-127], Benshangul-Gumuz $(n=6)[128,129]$, and Somali $(n=2)$ [130] national regional states. Types of hepatic disorders managed by these plants were hepatitis (42.33\%), jaundice (29.26\%), infections (3.13\%), cirrhosis (3.13\%), and nonspecific $(22.16 \%)$. Note that the summation of percent is more than $100 \%$ because of the sharing of medicinal plants among regions.

\section{Frequently used medicinal plants}

The most frequently utilized plant species were Justicia schimperiana (34.34\%), Croton macrostachyus (20.20\%), Phytolacca dodecandra (20.20\%), Cordia africana (10.10\%), Cucumis ficifolius (10.10\%), and Rumex abyssinica (10.10\%), as shown in Fig. 2.

\section{Growth forms and utilized parts}

Herbs (47.10\%), shrubs (26.09\%), trees (20.65\%), climbers (3.62), and others (including succulents, lianas, and twigs; $2.54 \%$ ) were the growth forms, while leaves $(34.30 \%)$, roots $(33.06 \%)$, and bark $(8.88 \%)$ were the common parts of medicinal plants utilized, as shown in Fig. 3.

They were used in the form of fresh (30.97\%), dry $(6.78 \%)$, either fresh or dry $(15.63 \%)$, and not available (46.61\%).

\section{Mode of preparation and administration}

Water was the most frequently $(51.38 \%)$ used additive for the preparation and administration of herbs, followed by milk products $(16.02 \%)$, honey $(11.60 \%)$, and others, as shown in Fig. 4.

The most common techniques used for the preparation and administration of medicinal plants were pounding (24.17\%), decoction (19.67\%), powdering $(9.72 \%)$, concoction $(9.24 \%)$, and others, as shown in Fig. 5.

Oral route was the most common $(76.35 \%)$ route for the administration of the herbs followed by dermal (6.68\%), inhalational (5.14\%), nasal (3.34\%), body washing $(3.57 \%)$, and whole body (1.03\%), while $4.88 \%$ of preparations had not available.

\section{Discussion}

Claimed medicinal plants of cultural importance are vital for the origin and basis of pharmacology and therapeutics. Ethnobotany and ethnopharmacology are useful strategies and viable vehicles for pharmaceutical research and drug discovery [13]. Approximately $80 \%$ of pharmacologically active plant-derived compounds were discovered after following up on the ethnomedicinal use of plants. The search for new and effective drugs and candidates based on ethnobotanical and ethnopharmacological approaches has proven to be more predictive when compared to random screening approaches. Hence, ethnopharmacological use of plants is a basis for phytochemical and phytopharmacological investigation [130-132]. 


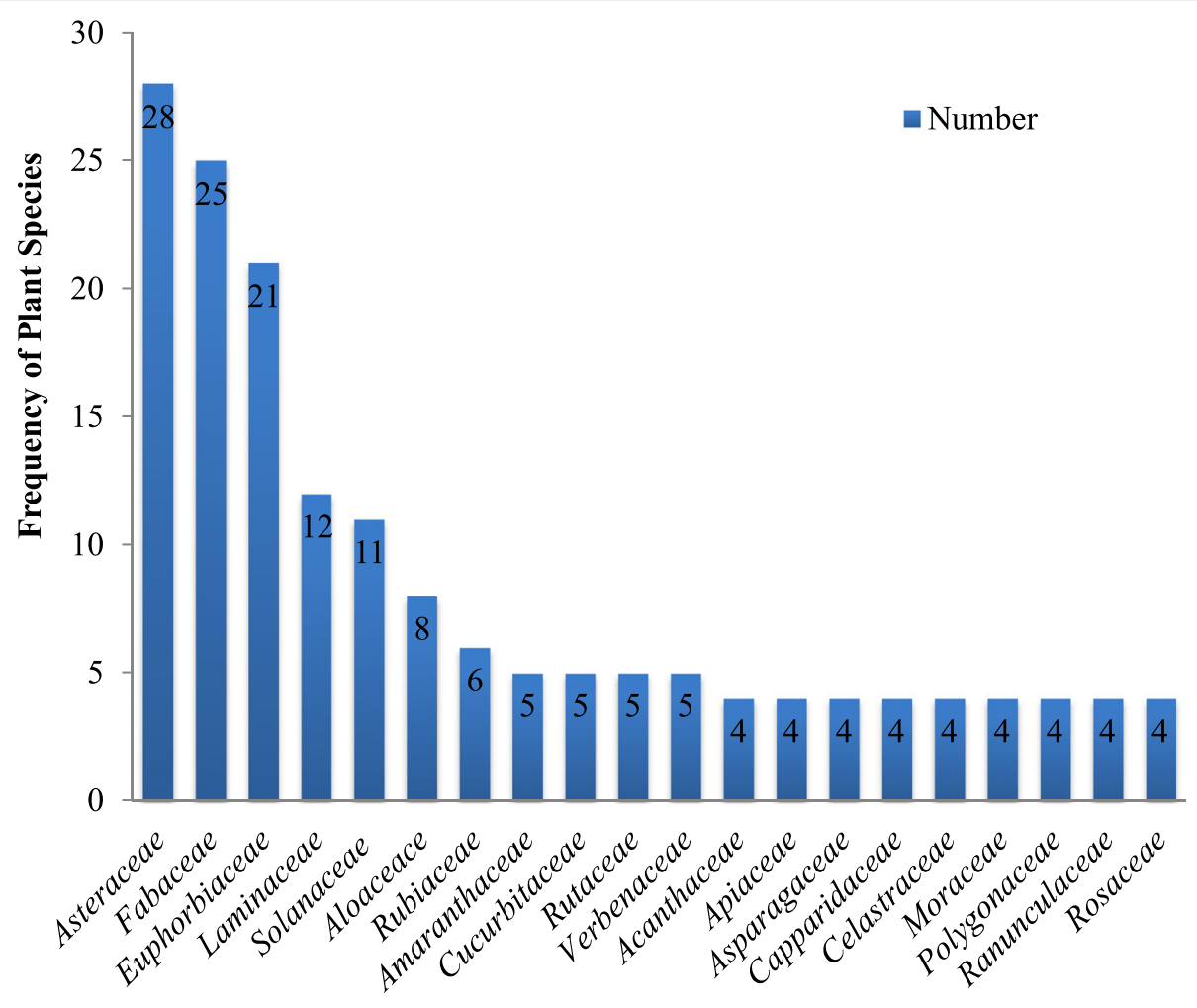

Families

Fig. 1 Frequently used plant families for the treatment of hepatic disorders in Ethiopia

Reviews on ethnomedicinal uses are vital and starting points for the selection and identification of commonly used medicinal plants. Frequently used or cited medicinal plants by indigenous people have been shown more pharmacologically active than plants used at ones or not at all. In addition, these reviews are vital for the documentation and preservation of indigenous ethnomedicinal practices. Such evidence is pertinent for prioritizing future phytochemical, pharmacological, and toxicological research agendas [133-135].

The current review identified a total of 276 plant species that were utilized for the treatment of hepatic disorders in Ethiopia. These plants make up 3.94\% of higher plant species in the country. This indicates that African flora, especially Ethiopian's holds enormous potential for the development of phytomedicines [136]. They are mainly distributed in the Oromia region, being the largest region in terms of area and population density as well as diversity of cultural practices. The southern nations, nationalities, and people region is the second region because of the existence of diversified ethnic groups and cultural practices, while Amhara is the third region due to extensive ethnomedicine practitioners by the Ethiopian Orthodox Church (like "Mergetas" and "Debteras") [137].

The most frequently utilized medicinal plants were from the Asteraceae and Fabaceae families. This was in agreement with other reviews [137-143]. These families contain several phytochemicals that possess strong antioxidant, free radicalscavenging, and antilipoperoxidant activities, including flavonoids, terpenoids, polyphenols, alkaloids, saponins, vitamins, enzymes, polysaccharides, lignin, xanthones, and pigments. These herbal products may cure different hepatic disorders by protecting the cells from damage caused by free radicals [144-146]. Frequent citation of particular plant species or families could indicate potentially higher bioactive hepatoprotectants [133].

Herbs constituted the largest growth habit, followed by shrubs and trees. This was in agreement with other reviews [133, 139, 147-150]. Their extensive use in the preparation of herbal medicines might be linked to their easy propagation, availability, and accessibility in the country. Because of their easy accessibility to various microorganisms, insects, and animals, they defended themselves by producing diverse offensive and defensive phytochemicals. These phytochemicals might have 


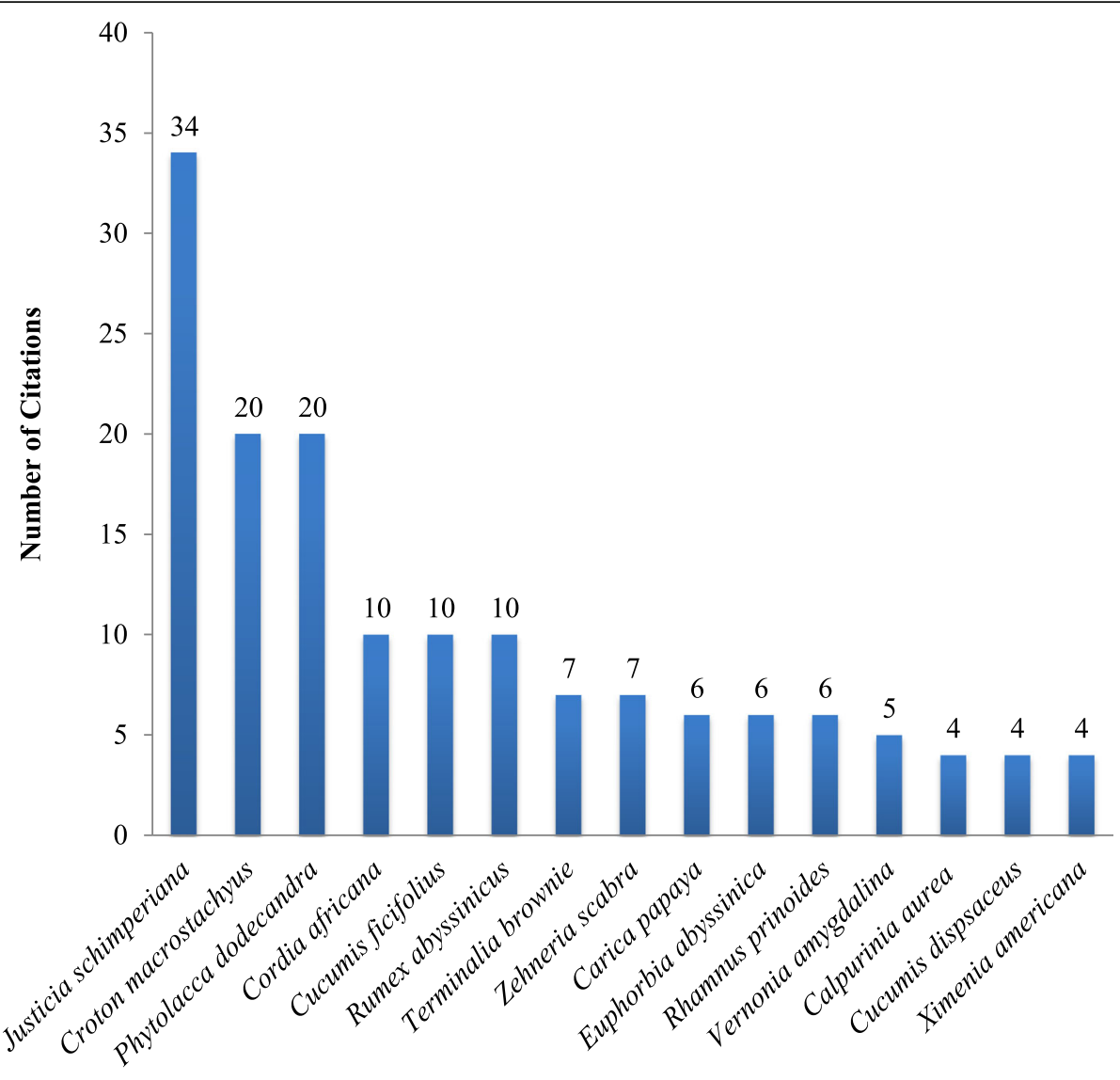

Plant Species

Fig. 2 Frequently used plant species for the treatment of hepatic disorders in Ethiopia

diverse biological effects, including therapeutic benefits, when exposed to other life forms. However, harvesting herbaceous plants for medicinal purposes is not sustainable as it threatens the survival of the plants. But herbs might not exist in dry seasons; hence, cultivation of medicinal plants, including medicinal plants gardens and lands are vital to sustain their availability throughout the year. Leaves were the dominant plant parts used, followed by roots and barks and this was in agreement with others [133, 139, 140, 148-151]. Frequent use of the leaf part of the plant might be its site of secondary metabolite production and easily formulation into different dosage forms. But their aggressive use of these plant parts might threaten and endanger the life of the plant.

The popular method for preparation was pounding, followed by decoction, powdering, and concoction. The current review was similar to other reviews $[133,138,140$, 141, 147]. Pounding is the preliminary method for the preparation of medicinal herbs, especially in fresh form. This was done by local stones and/or wood. However, there is a great concern that is risk of contamination. In decoction, the plant material was immersed in water in a pot and then heated. Heating might be required for extraction of the phytochemicals from the plant material. The extracted fluid was drunken after filtration through cloth and cooling. If the plant material is not easily available, powdering is the commonly used technique to preserve plant material for a long period of time.

Water was the common solvent used for the preparation and administration of herbal remedies. Water has a high capability to extract different phytochemicals from plant materials because it highest solvent properties and captures heat. The other additives used were honey, milk, butter, Eragrostis tef flour, local alcoholic drinks, sugars, salts, and spices. These additives were used for masking off objectionable tastes, smells, and colors of the remedies. They also used as antidotes for the poisonings of the herbs. The prepared remedies were generally administered orally. This was similar to other studies $[138,139]$. This is the simplest, convenient, and inexpensive route that might make the common route for the administration of herbs.

Most reviewed articles had some important and critical information gabs, including herbal preparation, 


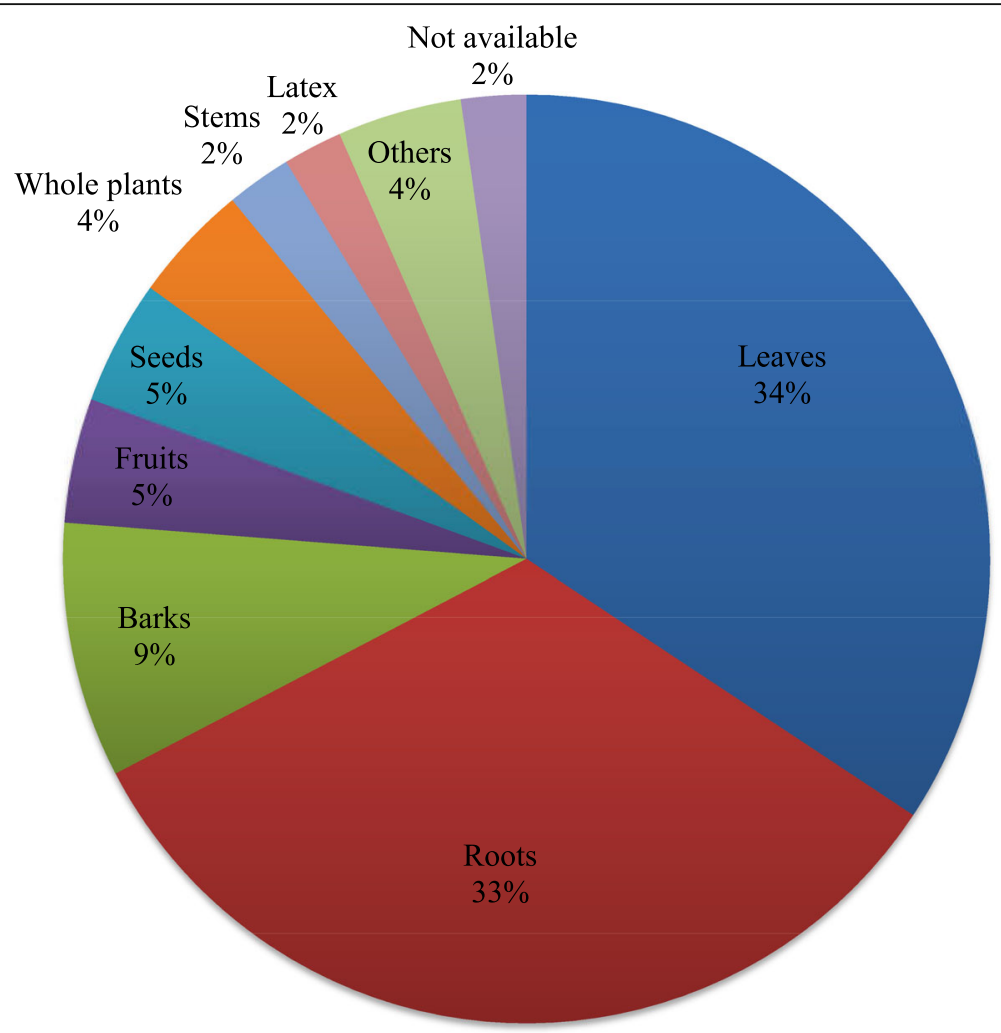

Fig. 3 Percentage of plant parts used for the treatment of hepatic disorders in Ethiopia

dosage regimens (for adults, elders, pregnant women, children), adverse effects, precautions, contraindications, antidotes, and the current risk status of medicinal plants. Complete information and standardized reporting systems are needed for future ethnomedicinal studies on indigenous medicinal plants in Ethiopia. In addition, study quality inconsistencies were noted with regard to sampling and the number of knowledgeable informants.

African traditional medical practices, especially Ethiopian's is currently challenged with problems of continuity and sustainability. Medicinal plants are the backbones of such practices. However, these plants are adversely affected by anthropogenic and natural forces. They are mostly obtained from wild habitants, which are currently threatened by deforestation, overgrazing, drought, commercialization, diseases, pests, agricultural expansion, firing, charcoal, population overgrowth, urbanization, construction, pollution, and climate change. Many medicinal plants have become endangered, threatened, at risk, and even extinct. These plants and indigenous practices might be lost forever without proper documentation and preservation. In addition to medicinal use, they are also used as food, closing, shelter, fuel, fiber, income generation, and the fulfilling of cultural and spiritual needs throughout the world. These practices further threaten these plants [133, 152, 153]. Hence, synthetic cultivation of medicinal plants and further conservation and documentation are recommended.

Some medicinal plants used for hepatic disorders showed promising pharmacologic activities; even though, the pharmacologic screening was at a preliminary stage. Some of their reported pharmacologic activities include hepatoprotective (Nigella sativa [154], Ocimum lamiifolium [155], and Stephania abyssinica [156]), antioxidant (Carica papaya and Vernonia amygdalina [157, 158], Ajuga integrifolia [158], Ocimum lamifolium and Lepidium sativum [159], and Rhamnus prinoides [160]), antiinflammatory (Carduus schimperi [161] and Rumex abyssinicus [162]), and antioxidant and antiinflammatory (Vernonia amygdalina [163]).

\section{Conclusions}

The current review showed that many claimed medicinal plants were utilized for the management of different hepatic disorders in Ethiopia. Therefore, further experimental studies are recommended to assure their safety, efficacy (antioxidant, anti-inflammatory, anticarcinogenic, antifibrotic, and antiviral activities), phytochemistry, and quality. Documentation and preservation of ethnobotanical indigenous knowledge, 


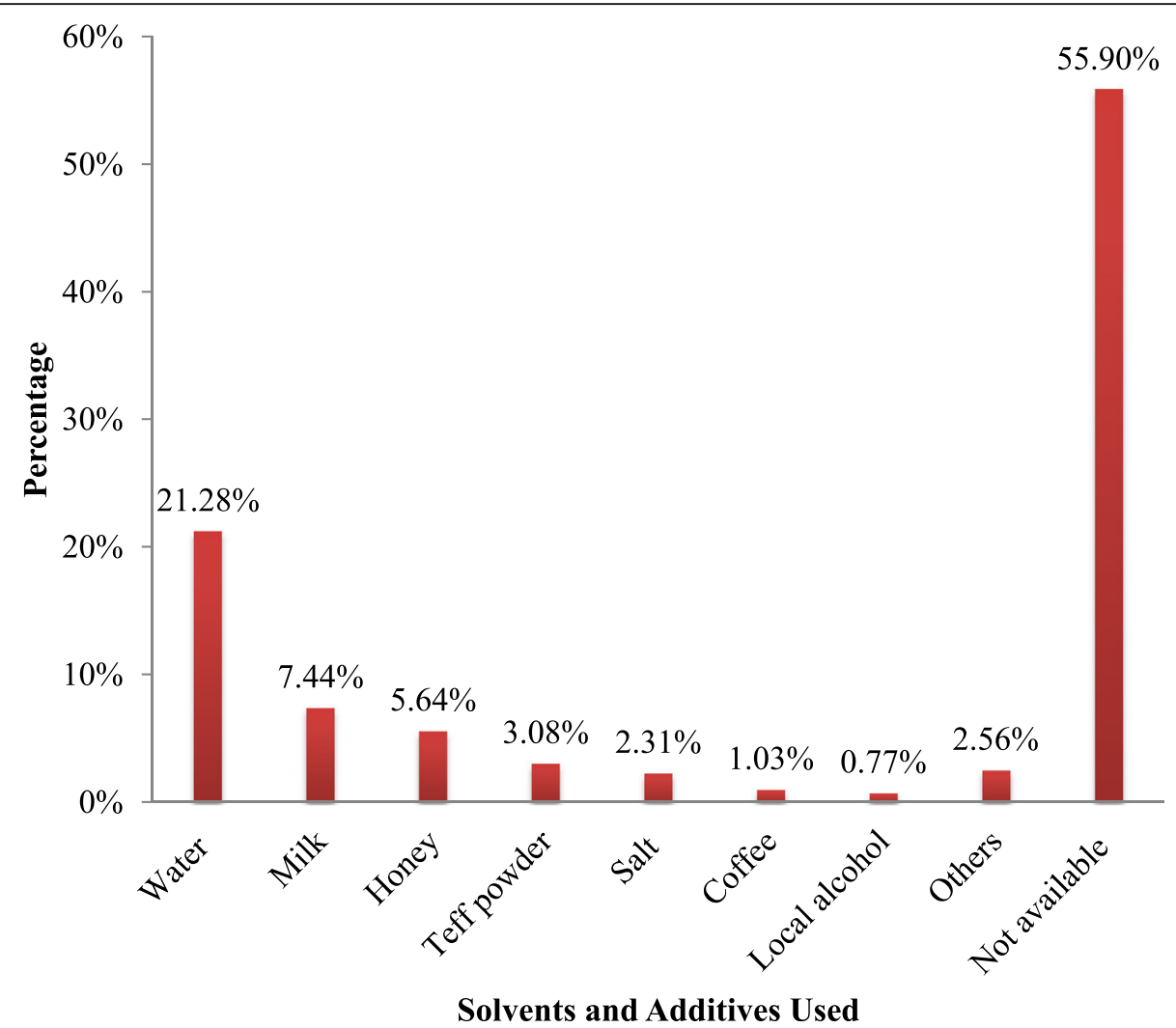

Fig. 4 Solvents and additives used for the preparation of plants for hepatic disorders in Ethiopia

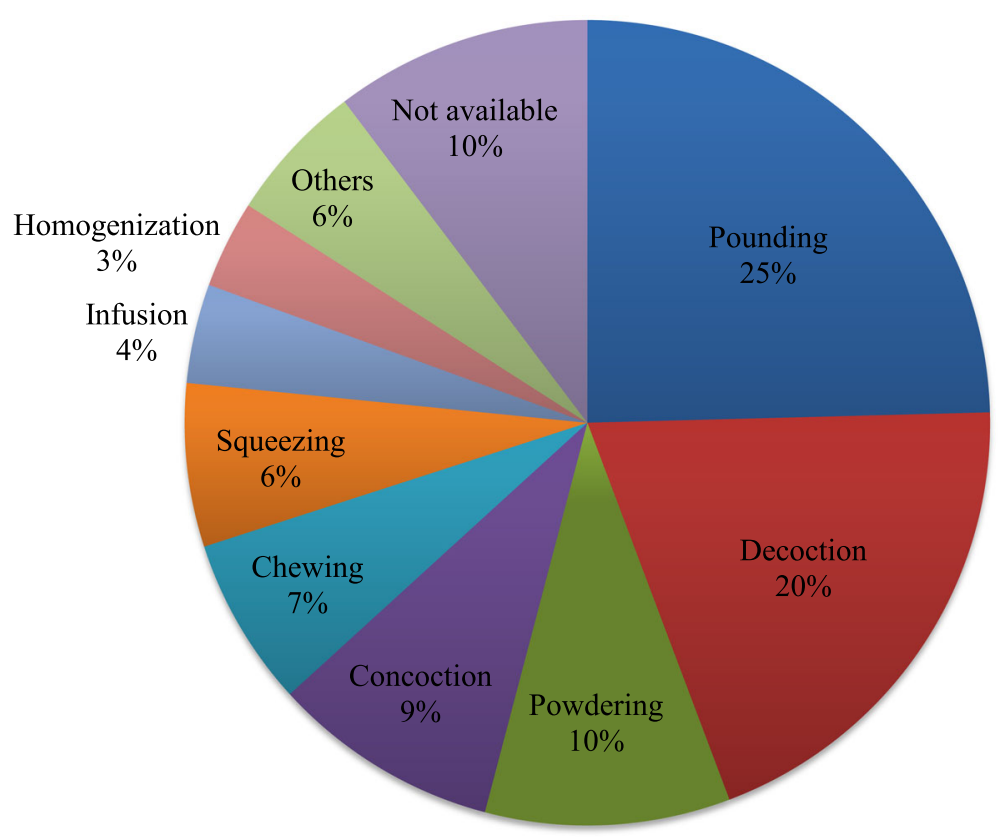

Fig. 5 Methods of preparation of plants used for the treatment of hepatic disorders in Ethiopia 
which contributes to drug development, before they are lost due to environmental and anthropogenic factors, are also strengthened.

\section{Supplementary information}

Supplementary information accompanies this paper at https://doi.org/10. 1186/s40816-020-00195-8.

Additional file 1 Supplementary material 1. Ethnopharmaceutica information on medicinal plants utilized for the management of different hepatic disorders in Ethiopian traditional medical practices.

\section{Acknowledgements}

We would like to thank Mr. Selamu Kebamo for his constructive suggestions and comments.

\section{Authors' contributions}

ABM is the guarantor. He contributed substantially to the conception and design of the study, and the acquisition and analysis of the data. The draft and critical revision of the manuscript were made by ABM. The final approval of the manuscript version was done by ABM and MWA

\section{Funding}

Not applicable.

\section{Availability of data and materials}

All data generated or analyzed during this study are included in this published article and its supplementary information file.

\section{Ethics approval and consent to participate}

Not applicable.

\section{Consent for publication}

Not applicable.

\section{Competing interests}

The authors declare that they have no competing interests.

\section{Author details}

'Department of Pharmacy, College of Medicine and Health Sciences, Bahir Dar University, Bahir Dar, Ethiopia. ²Department of Pharmacy, College of Health Sciences, Debre Markos University, Debre Markos, Ethiopia.

Received: 17 March 2020 Accepted: 7 July 2020

Published online: 29 July 2020

\section{References}

1. Trefts E, Gannon M, Wasserman DH. The liver. Curr Biol. 2017:27:1147-51.

2. Moradi MT, Asadi-Samani M, Bahmani M. Medicinal plants used for hepatic disorders based on the ethnobotanical documents of Iran: a review. Int J PharmTech Res. 2016:9:407-15.

3. Asadi-Samani M, Kafash-Farkhad N, Azimi N, Fasihi A, Alinia-Ahandani E, Rafieian-Kopaei M. Medicinal plants with hepatoprotective activity in Iranian folk medicine. Asian Pac J TroP Biomed. 2015;5:146-57.

4. Teles SA. Viral hepatitis: a challenge for nursing. Rev Bras Enferm. 2017;70: 231-2.

5. Wijayagunawardanea MPB, Wijerathnea CUB, Herathb CB. Indigenous herba recipes for treatment of liver cirrhosis. Procedia Chem. 2015;14:270-6.

6. Sri PU, Leelavathi $\mathrm{V}$, Manjusha DL, Anusha B, Swapna G. A comprehensive review on hepatoprotective activity of the selected medicinal plants. Int J Res Eng Appl Sci. 2016;6:7-23.

7. Saleem M, Naseer F. Medicinal plants in the protection and treatment of liver diseases. Bangladesh J Pharmacol. 2014;9:511-26.

8. Jayachandra K, Devi VS. Development of herbal drugs in the treatmen of jaundice: an overview. Int J Ayurvedic Herb Med. 2012;2:636-45.

9. Anand K, Lal UR. Hepatitis and medicinal plants: an overview. J Pharmacogn Phytochem. 2016;5:408-15.

10. Shakya AK. Medicinal plants: future source of new drugs. Int J Herb Med. 2016:4:59-64.
11. Mamedov N. Medicinal plants studies: history, challenges and prospective Med Aromat Plants. 2012;1:8

12. Qazi AM, Molvi IK. Herbal medicine: a comprehensive review. Int J Pharm Res. 2016;8:2.

13. Lopez V. Are traditional medicinal plants and Ethnobotany still valuable approaches in pharmaceutical research? Bol Latinoam Caribe Plant Med Aromat. 2011;10:3-10

14. Patwardhan B, Vaidya ADB, Chorghade M. Ayurveda and natural products drug discovery. Curr Sci. 2004;86:789-99.

15. Pawar HA. Natural products as a source of lead to the design of new drugs. Nat Prod Chem Res. 2014:2:2-4.

16. Fullas F. Ethiopian traditional medicine: common medicinal plants in perspective. J Black Stud. 2002:32:610-2.

17. Jachak SM, Saklani A. Challenges and opportunities in drug discovery from plant. Curr Sci. 2007:92:1251-7.

18. Kaur K, Jain M, Kaur T, Jain R. Antimalarials from nature. Bioorg Med Chem. 2009:30:30.

19. Kahumba J, Rasamiravaka T, Okusa PN, Bakari A, Bizumukama L, Kalonji JB, et al. Traditional African medicine: from ancestral knowledge to a modern integrated future. Science. 2015;20:60-3.

20. Nikkhajoei M, Choopani R, Tansaz M, Heydarirad G, Hashem-Dabaghian F, Sahranavard S, et al. Herbal medicines used in treatment of nonalcoholic fatty liver disease: a mini-review. GMJ. 2016;5:107-13.

21. Kassaye KD, Amberbir A, Getachew B, Mussema Y. A historical overview of traditional medicine practices and policy in Ethiopia. Ethio J Heal Dev. 2006; 20:127-34

22. Gall A, Shenkute Z, Kiefer D, Jackson JC. Ethiopian traditional and herbal medications and their interaction with conventional drugs. 2009. http:// ethnomed.org.

23. Tadesse M, Mesfin B. A review of selected plants used in the maintenance of health and wellness in Ethiopia. Ee-JRIF. 2010;2:85-102.

24. Lemessa D, Teka Y. Patterns of the diversity of characteristic species across vegetation ecosystems of Ethiopia. Ecol Evol Biol. 2017;2:34-44.

25. Rout SP, Choudary KA, Kar DM, Das L, Jain A. Plants in traditional medicinal system-future source of new drugs. Int J Pharm Pharm Sci. 2009;1:1.

26. Hoareau L, DaSilva EJ. Medicinal plants: a re-emerging health aid. Electron J Biotechnol. 1999;2:56-70

27. Poorna RL, Mymoon M, Hariharan A. Preservation and protection of traditional knowledge-diverse documentation initiatives across the globe. Curr Sci. 2014;107:1240-6.

28. El-Ghani MMA. Traditional medicinal plants of Nigeria: an overview. Agric Biol J N Am. 2016:7:220-47.

29. Willcox ML, Bodeker G. Clinical review traditional herbal medicines for malaria. BMJ. 2004;329:1156-9.

30. Mojab F. Antimalarial natural products: a review. Avicenna J Phytomedicine. 2012;2:52-62.

31. Kazembe T, Munyarari $\mathrm{E}$, Charumbira I. Use of traditional herbal medicines to cure malaria. Bull Environ Pharmacol Life Sci. 2012;1:63-84.

32. Dhiman A, Sharma K, Sharma A, Sindhu P. A review on the status of quality control and standardization of herbal drugs in India. Drug Dev Ther. 2016;7: 107-12.

33. Firenzuoli F, Gori L. Herbal medicine today: clinical and research issues. eCAM. 2007:4:37-40

34. Calixto JB. Efficacy, safety, quality control, marketing and regulatory guidelines for herbal medicines (Phytotherapeutic agents). Braz J Med Biol Res. 2000:33:179-89.

35. Tesfaye, T: Use and Management of Medicinal Plants by People of Melkabelo Woreda, East Hararghe, Oromia Region, Ethiopia. 2016. http:// hulirs.haramaya.edu.et/handle/123456789/2873.

36. Abebe M. Ethnobotanical study of traditional medicinal plants of Gololcha District, Bale Zone of Oromia Region, Ethiopia. 2013. http://hulirs.haramaya. edu.et/handle/123456789/3253show=full(2013)

37. Yinger $\mathrm{H}$, Kelbessa $\mathrm{E}$, Bekele $\mathrm{T}$, Lulekal $\mathrm{E}$. A study on the Ethnobotany of medicinal plants and floristic composition of the dry Afromontane Forest at Bale mountains national park. Ethiopia Ethiop J Sci. 2008;31:103-20.

38. Demisie Z. Survey and identification of traditional medicinal plants in sure Woreda. Ethiopia: Arsi Zone; 2016. http://etd.aau.edu.et/bitstream/123456 789/12279/1.

39. Parvez N, Yadav S. A survey of ethnopharmacology of single herbal preparations of medicinal plants in Asendabo District. Jimma Cont J Pharm Sci. 2008:2:15-26. 
40. Kitaba, NT: Ecology and plant use diversity in Sof Umer area of bale, southeastern Ethiopia. 2006. http://etd.aau.edu.et/bitstream/123456 789/54/1/Negusse20Tadesse.pdf.

41. Duressa, TR: Vascular plant diversity and Ethnobotanical study of medicinal and wild edible plants in Jibat, Gedo and Chilimo Forests, West Shewa Zone of Oromia Region, Ethiopia. 2016. http://etd.aau.edu.et/handle/123456 789/13720.

42. Lulekal E, Kelbessa E, Bekele T, Yineger H. An Ethnobotanical study of medicinal plants in Mana Angetu District, Southeastern Ethiopia. J Ethnobiol Ethnomed. 2008:4:10.

43. Eshete MA. Vascular plants diversity and Ethnobotany with emphasis to traditional medicinal and wild edible plants in Dugda Dawa District of Borana Zone, Oromia Regional State, Ethiopia. 2017. http://etd.aau.edu.et/ handle/123456789/15423.

44. Eshete MA, Kelbessa E, Dalle G. Ethnobotanical study of medicinal plants in Guji agro-pastoralists, blue Hora District of Borana Zone, Oromia Region, Ethiopia. Int J Res Eng Appl Sci. 2016;4:170-84.

45. Yineger $\mathrm{H}$, Yewhalaw D. Traditional medicinal plant knowledge and use by local healers in Sekoru District, Jimma Zone, Southwestern Ethiopia. J Ethnobiol Ethnomed. 2007;3:24.

46. Luizza MW, Young H, Evangelista P, Worede A, Bussmann RW, Weimer A. Local knowledge of plants and their uses among women in the Bale Mountains, Ethiopia. Ethnobot Res Appl. 2013;11:315-39.

47. Enyew A, Asfaw Z, Kelbessa E, Nagappan R. Status of medico-cultural commercial plants at fiche town market, Ethiopia. Int J Pharm H Care Res. 2013;1:227-36

48. Kumbi ET. Use and conservation of traditional medicinal plants by indigenous people in Gimbi Woreda, Western Wellega, Ethiopia. 2007. http://etd.aau.edu.et/handle/123456789/132

49. Gebrehiwot M. An ethnobotanical study of medicinal plants in Seru Woreda, Arsi Zone, Oromia Region, Ethiopia. 2010. http://etd.aau.edu.et/ bitstream/123456789/277/3/Mengistu20Gebrehiwot.pdf.

50. Gabriel T, Guji T. Ethnopharmacological survey of medicinal plants in Agaro District, Jimma Zone, Southwest Ethiopia. Int J Pharm Sci Res. 2014;5:3551-9.

51. Etana B. Ethnobotanical study of traditional medicinal plants of Goma Wereda, Jima Zone of Oromia Region, Ethiopia. 2010. http://hulirs.haramaya. edu.et/bitstream/handle/123456789/3253.

52. Fenetahun $Y$, Eshetu G. A review on ethnobotanical studies of medicinal plants use by agro-pastoral communities in Ethiopia. J Med Plants Stud. 2017:5:33-44.

53. Amenu E. Use and management of medicinal plants by indigenous people of Ejaji Area, West Shoa, Ethiopia: an ethnobotanical approach. 2007. http:// etd.aau.edu.et/handle/123456789/131.

54. Suleman S, Alemu T. A survey on utilization of Ethnomedicinal plants in Nekemte town, east Wellega (Oromia), Ethiopia. J Herbs Spices Med Plants. 2012;18:34-57.

55. Tadesse M, Hunde D, Getachew Y. Survey of medicinal plants used to treat human disease in Seka Chekorsa District, Jimma zone, Ethiopia. Ethiop J Heal Sci. 2005;15:89-107.

56. Sori T, Bekana M, Adugna G, Kelbessa E. Medicinal plants in the ethnoveterinary practices of Borana pastoralists, southern Ethiopia. Intern J Appl Res Vet Med. 2004;2:220-5.

57. Abera B. Medicinal plants used in traditional medicine by Oromo people, Ghimbi District, Southwest Ethiopia. J Ethnobiol Ethnomed. 2014;10:41-55.

58. Kefalew A, Asfaw Z, Kelbessa E. Ethnobotany of medicinal plants in Ada'a district, east Shewa zone of Oromia regional state, Ethiopia. J Ethnobiol Ethnomed. 2015;11:25.

59. Misha G, Yarlagadda R, Woldemariam M. Knowledge, attitude, practice and management of traditional medicine among people of Shopa Bultum, Southeast Ethiopia. Res J Pharm Biol Chem Sci. 2014;5:152-70.

60. Gashe F, Worku F. Ethnopharmacological survey of medicinal plants used for the treatment of human diseases in Abay-Chomen District, eastern Wollega zone, Western Ethiopia. Ethiop J Heal Sci. 2007:17:131-46

61. Giday K, Lenaerts L, Gebrehiwot K, Yirga G, Verbist B, Muys B. Ethnobotanical study of medicinal plants from degraded dry Afromontane Forest in northern Ethiopia: species, uses and conservation challenges. J Herb Med. 2016;30:30.

62. Bekele G, Reddy PR. Ethnobotanical study of medicinal plants used to treat human ailments by Guji Oromo tribes in Abaya District, Borana, Oromia, Ethiopia. Univers J Plant Sci. 2015;3:1.
63. Alito MK. Use and management of medicinal plants by indigenous people of Jima Rare District, Oromia Region, Ethiopia. 2014. http://hulirs.haramaya. edu.et/handle/123456789/3258

64. Megersa M, Asfaw Z, Kelbessa E, Beyene A, Woldeab B. An Ethnobotanical study of medicinal plants in Wayu Tuka District, east Welega zone of Oromia regional state, West Ethiopia. J Ethnobiol Ethnomed. 2013;9:68.

65. Avigdor E, Wohlmuth $H$, Asfaw Z, Awas T. The current status of knowledge of herbal medicine and medicinal plants in fiche, Ethiopia. J Ethnobiol Ethnomed. 2014;10:38.

66. Birhanu T, Abera D, Ejeta E. Ethnobotanical study of medicinal plants in selected Horro Gudurru Woredas, Western Ethiopia. J Biol Agric Healthc. 2015:5:83-93.

67. Wondimu T, Asfaw Z, Kelbessa E. Ethnobotanical study of medicinal plants around Dheeraa town, Arsi zone, Ethiopia. J Ethnopharmacol. 2007;112:152-61.

68. Hunde D, Asfaw Z, Kelbessa E. Use of traditional medicinal plants by people of "Boosat" sub-district, central eastern Ethiopia. Ethiop J Heal Sci. 2006;16: $141-55$.

69. Kewessa G, Abebe T, Demessie A. Indigenous knowledge on the use and Management of Medicinal Trees and Shrubs in Dale District, Sidama zone, Southern Ethiopia. Ethnobot Res Appl. 2015;14:171-82.

70. Agize M, Demissew S, Asfaw Z. Ethnobotany of medicinal plants in Loma and Gena Bosa districts of Dawro zone, Southern Ethiopia. Topcls J Herb Med. 2013;2:194-212.

71. Beyene ST. An ethnobotanical study of medicinal plants in Wondo Genet Natural Forest and Adjacent Kebeles, Sidama Zone, SNNP Region, Ethiopia. 2011. http://etd.aau.edu.et/handle/123456789/244.

72. Temam T, Dillo A. Ethnobotanical study of medicinal plants of MirabBadwacho District, Ethiopia. J BioSci Biotechnol. 2016;5:151-8.

73. Bekalo TH, Woodmatas SD, Woldemariam ZA. An Ethnobotanical study of medicinal plants used by local people in the lowlands of Konta special Woreda, southern nations, nationalities and peoples regional state, Ethiopia. J Ethnobiol Ethnomed. 2009;5:26.

74. Regassa R. Assessment of indigenous knowledge of medicinal plant practice and mode of service delivery in Hawassa City, Southern Ethiopia. J Med Plants Res. 2013;7:517-35.

75. Kassa Z, Asfaw Z, Demissew S. An Ethnobotanical study of medicinal plants in Sheka zone of southern nations, nationalities and people regional state, Ethiopia. J Ethnobiol Ethnomed. 2020;16:7. https://doi.org/10.1186/s13002020-0358-4.

76. Mesfin F, Demissew S, Teklehaymanot T. An Ethnobotanical study of medicinal plants in Wonago Woreda, SNNPR, Ethiopia. J Ethnobiol Ethnomed. 2009:5:28.

77. Tolossa K, Debela E, Athanasiadou S, Tolera A, Ganga G. Ethnomedicinal study of plants used for treatment of human and livestock ailments by traditional healers in south Omo, Southern Ethiopia. J Ethnobiol Ethnomed. 2013:9:32.

78. Doffana ZD. Sacred natural sites, herbal medicine, medicinal plants and their conservation in Sidama, Ethiopia. Cogent Food Agric. 2017;3:1.

79. Maryo M, Nemomissa S, Bekele T. An Ethnobotanical study of medicinal plants of the Kembatta ethnic group in Enset-Based Agricultural Landscape of Kembatta Tembaro (KT) zone, southern Ethiopia. Asian J Plant Sci Res. 2015;5:42-61.

80. Legese GA. Plant diversity and ethnobotany of medicinal and wild edible plants in Amaro District of Southern Nations, Nationalities and Peoples Region and Gelana District of Oromia Region, Southern Ethiopia. 2017. http://etd.aau.edu.et/bitstream/123456789/16419/1/ Getu\%20Alemayehu.pdf.

81. Paulos B, Fenta TG, Bisrat D, Asres K. Health seeking behavior and use of medicinal plants among the Hamer ethnic group, south Omo zone, Southwestern Ethiopia. J Ethnobiol Ethnomed. 2016;12:44.

82. Giday M, Asfaw Z, Woldu Z, Teklehaymanot T. Medicinal plant knowledge of the bench ethnic group of Ethiopia: an ethnobotanical investigation. J Ethnobiol Ethnomed. 2009;5:34

83. Mesfin F, Seta T, Assefa A. An ethnobotanical study of medicinal plants in Amaro Woreda, Ethiopia. Ethnobot Res Appl. 2014;12:341-54.

84. Ragunathan M, Abay SM. Ethnomedicinal survey of folk drugs used in Bahirdar Zuria District, Northwestern Ethiopia. Indian J Tradit Knowl. 2009;8:281-4.

85. Teklehaymanot T, Giday M, Medhin G, Mekonnen Y. Knowledge and use of medicinal plants by people around Debre Libanos monastery in Ethiopia. J Ethnopharmacol. 2007;111:271-83. 
86. Mekuanent T, Zebene A, Solomon Z. Ethnobotanical study of medicinal plants in Chilga District, Northwestern Ethiopia. J Nat Remedies. 2015;15:88112.

87. Abebe E. Ethnobtanical study on medicinal plants used by local communities in Debark Woreda, North Gondar Zone, Amhara Regional State, Ethiopia. 2011. http://etd.aau.edu.et/handle/123456789/373.

88. Lulekal E, Asfaw Z, Kelbessa E, Damme PV. Ethnomedicinal study of plants used for human ailments in Ankober District, north Shoa zone, Amhara region, Ethiopia. J Ethnobiol Ethnomed. 2013;9:63.

89. Teklehaymanot T. Ethnobotanical study of knowledge and medicinal plants use by the people in Dek Island in Ethiopia. J Ethnopharmacol. 2009;124:6978.

90. Getnet Z, Chandrodyam S, Masresha G. Studies on traditional medicinal plants in Ambagiorgis area of Wogera District, Amhara regional state, Ethiopia. Int J Pure App Biosci. 2016:4:38-45.

91. Legese GA, Kelbessa E, Asfaw Z. Ethnobotanical study of medicinal plants used by local communities of Minjar-Shenkora District, north Shewa zone of Amhara region, Ethiopia. J Med Plants Stud. 2015;3:6.

92. Amsalu N. An ethnobotanical study of medicinal plants in Farta Wereda, South Gonder Zone of Amhara Region, Ethiopia. 2010. http://etd.aau.edu.et/ handle/123456789/1432.

93. Gebeyehu G, Asfaw Z, Enyew A, Raja N. Ethnobotanical study of traditional medicinal plants and their conservation status in Mecha Woreda, west Gojjam zone, Ethiopia. Int J Pharm H Care Res. 2014;2:137-54.

94. Teklehaymanot T, Giday M. Ethnobotanical study of medicinal plants used by people in Zegie peninsula, Northwestern Ethiopia. J Ethnobiol Ethnomed. 2007:3:12.

95. Chekole G. Ethnobotanical study of medicinal plants used against human ailments in Gubalafto District, Northern Ethiopia. J Ethnobiol Ethnomed. 2017;13:1.

96. Meragiaw M, Asfaw Z, Argaw M. The status of ethnobotanical knowledge of medicinal plants and the impacts of resettlement in Delanta, Northwestern Wello, Northern Ethiopia. Evidence-Based Complement Altern Med. 2016. https://doi.org/10.1155/2016/5060247.

97. Chekole G, Asfaw Z, Kelbessa E. Ethnobotanical study of medicinal plants in the environs of Tara-gedam and Amba remnant forests of Libo Kemkem District, Northwest Ethiopia. J Ethnobiol Ethnomed. 2015;11:4.

98. Wubetu M, Abula T, Dejenu G. Ethnopharmacologic survey of medicinal plants used to treat human diseases by traditional medical practitioners in Dega Damot District, Amhara, Northwestern Ethiopia. BMC Res Notes. 2017;10:157.

99. Reta H. An ethnobotanical study of useful plants of the farming site in Gozamen Wereda, East Gojjam Zone of Amhara Region, Ethiopia. 2010. http://etd.aau.edu.et/handle/123456789/316?mode=full.

100. Berhanu A, Asfaw Z, Kelbessa E. Ethnobotany of plants used as insecticides, repellents and antimalarial agents in Jabitehnan District, West Gojjam. Ethio J Sci. 2006;29:87-92.

101. Birhanu Z, Endale A, Shewamene Z. An ethnomedicinal investigation of plants used by traditional healers of Gondar town, Northwestern Ethiopia. J Med Plants Stud. 2015;3:36-43.

102. Belay $\mathrm{H}$. Ethnobotanical documentation of functional food plants around Debere Markos District, East Gojjam, Ethiopia. 2016. http://etd.aau.edu.et/ handle/123456789/12533.

103. Wassie SM, Aragie LL, Taye BW, Mekonnen LB. Knowledge, attitude, and utilization of traditional medicine among the communities of Merawi town, Northwest Ethiopia: a cross-sectional study. Evidence-Based Complement Altern Med. 2015. https://doi.org/10.1155/2015/138073.

104. Getaneh S, Girma Z. An Ethnobotanical study of medicinal plants in Debre Libanos Wereda, Central Ethiopia. Afr J Plant Sci. 2014;8:366-79.

105. Limenih Y, Umer S, Woldemariam M. Ethnobotanical study on traditional medicinal plants in Dega Damot Woreda, Amhara region, North Ethiopia. IJRPC. 2015;5:258-73.

106. Yirga G. Assessment of traditional medicinal plants in Endrta District, SouthEstern Tigray, Northern Ethiopia. Afr J Plant Sci. 2010;4:255-60.

107. Araya S, Abera B, Giday M. Study of plants traditionally used in public and animal health management in Seharti Samre District, southern Tigray, Ethiopia. J Ethnobiol Ethnomed. 2015;11:22.

108. Wereta, TB: Ethnobotany of medicinal plants in Erob and Gulomahda districts, Eastern Zone of Tigray Region, Ethiopia. 2015. http://etd.aau.edu.et/ handle/123456789/12103.

109. Zenebe G, Zerihun M, Solomon Z. An Ethnobotanical study of medicinal plants in Asgede Tsimbila District, northwestern Tigray, Northern Ethiopia. Ethnobot Res Appl. 2012;10:305-20
110. Hishe M, Asfaw Z. Review on Ethnobotanical studies on traditional medicinal plants used to treat livestock and human ailments in Tigray region, Ethiopia. Adv J Biol Sci Res. 2015;3:8-36.

111. Teklay A, Abera B, Giday M. An Ethnobotanical study of medicinal plants used in Kilte Awulaelo District, Tigray Region of Ethiopia. J Ethnobiol Ethnomed. 2013;9:65.

112. Yirga G, Teferi M, Kasaye M. Survey of medicinal plants used to treat human ailments in Hawzen District, Northern Ethiopia. Int J Biodvers Conserv. 2011; 3:709-14.

113. Moravec I, Fernandez E, Vlkova M, Milella L. Ethnobotany of medicinal plants of northern Ethiopia. Bol Latinoam Caribe Plant Med Aromat. 2014;13:126-34

114. Gebrezgabiher G, Kalayou S, Sahle S. An ethno-veterinary survey of medicinal plants in Woredas of Tigray region, Northern Ethiopia. Int J Biodivers Conserv. 2013;5:89-97.

115. Mehari AT. Ethnobotanical study of Dess'a Forest, Northeastern Escarpment of Ethiopia, with emphasis on use and management of forest resources by the local people. 2008. http://etd.aau.edu.et/handle/123456789/1048.

116. Mesfin K, Tekle G, Tesfay T. Ethnobotanical study of traditional medicinal plants used by indigenous people of Gemad District, Northern Ethiopia. J Med Plants Stud. 2013;1:32-7.

117. Teklehaymanot T. An Ethnobotanical survey of medicinal and edible plants of Yalo Woreda in Afar regional state, Ethiopia. J Ethnobiol Ethnomed. 2017;13:40

118. Beche D, Gebeyehu G, Feyisa K. Indigenous utilization and Management of Useful Plants in and around awash National Park, Ethiopia. J Plant Biol Soil Heal. 2016:3:1.

119. Yadav RH. Medicinal plants in folk medicine system of Ethiopia. J Poisonous Med Plant Res. 2013:1:7-11.

120. Fassil H. We do what we know: local health knowledge and home-based medicinal plant use in Ethiopia. 2003. http://citeseerx.ist.psu.edu/viewdoc/summary.

121. Tesfaye HT. Review on medicine plant uses in selected regions of Ethiopia. J Pharm Altern Med. 2017:14:38-41.

122. Ayalew S, Kebede A, Mesfin A, Mulualem G. Ethnobotanical study of medicinal plants used by agro-pastoralist Somali people for the Management of Human Ailments in Jeldesa cluster, Dire Dawa administration, Eastern Ethiopia. J Med Plants Res. 2017;11:171-87.

123. Belayneh A, Bussa NF. Ethnomedicinal plants used to treat human ailments in the prehistoric place of Harla and Dengego valleys, Eastern Ethiopia. J Ethnobiol Ethnomed. 2014;10:18.

124. Mohammed C, Abera D, Woyessa M, Birhanu T. Survey of ethno-veterinary medicinal plants in Melkabello District, eastern Harerghe zone, Eastern Ethiopia. Ethiop Vet J. 2016;20:2.

125. Belayneh A. Floristic Description and Ethnobotanical Study of the Natural Vegetation in the Babile Elephant Sanctuary, Ethiopia. 2006. http://etd.aau. edu.et/handle/123456789/16453.

126. Belayneh A, Asfaw Z, Demissew S, Bussa NF. Medicinal plants potential and use by pastoral and agro-pastoral communities in Erer Valley of Babile Wereda, Eastern Ethiopia. J Ethnobiol Ethnomed. 2012;8:1-11.

127. Fenetahun Y, Eshetu G, Worku A, Abdella T. A survey on medicinal plants used by traditional healers in Harari regional state, East Ethiopia. J Med Plants Stud. 2017:5:85-90.

128. Desissa D, Binggeli P. Uses and conservation status of medicinal plants used by the Shinasha people. 2002. http://www.mikepalmer.co.uk/ woodyplantecology/ethiopia/shinasha.html.

129. Mengesha GG. Ethnobotanical survey of medicinal plants used in treating human and livestock health problems in Mandura Woreda of Benishangul Gumuz, Ethiopia. Adv Med Plant Res. 2016;4:11-26.

130. Issa A. Ethnomedicinal study of plants in Jigjiga Woreda, eastern Ethiopia. 2015. http://etd.aau.edu.et/bitstream/123456789/8252/1/Arebu\%20lssa.pdf.

131. Leitao SG, de Oliveira DR. The modern pharmacognosy and the ethnopharmacological approach on natural products research. Rev Bras Farm. 2014;24:97-8.

132. Tougeer S. Ethnopharmacology and random screening. J Pharm Pharmacogn Res. 2015:3:45-6.

133. Esubalew ST, Belete A, Lulekal E, Gabriel T, Engidawork E, Asres K. Review of ethnobotanical and ethnopharmacological evidences of some Ethiopian medicinal plants traditionally used for the treatment of cancer. Ethiop J Heal Dev. 2017;31:161-87.

134. Awas T, Yohannes T. Contribution of the ethiopian Flora project to the Ethiopian plant biodiversity conservation and sustainable use. Ethiop J Biol Sci. 2014;32:69-76. 
135. Fabricant DS, Farnsworth NR. The value of plants used in traditional medicine for drug discovery. Environ Health Perspect. 2001;109:69-75.

136. Dasture AV. Global market potentials of Ayruveda drugs: some facts. Anc Sci Life. 2002;21:281-6.

137. Tilahun A, Terefe $H$, Soromessa T. The contribution of Ethiopian orthodox Tewahido Church in forest management and its best practices to be scaled up in north Shewa zone of Amhara region, Ethiopia. Agric For Fish. 2015;4: 123-37.

138. Mukazayirea MJ, Minanib V, Ruffob CK, Bizuruc E, Stévignya C, Dueza P. Traditional phytotherapy remedies used in southern Rwanda for the treatment of liver diseases. J Ethnopharmacol. 2011;138:415-31.

139. Maroyi A. Traditional use of medicinal plants in south-Central Zimbabwe: review and perspectives. J Ethnobiol Ethnomed. 2013;9:31.

140. Mahwasane ST, Middleton L, Boaduo N. An ethnobotanical survey of indigenous knowledge on medicinal plants used by the traditional healers of the Lwamondo area, Limpopo Province, South Africa. South African J Bot. 2013;88:69-75.

141. Kalaskar MG, Surana SJ. Ethnomedicinal plants used against liver disease among the tribes of India: review. J Biol Sci. 2014;14:154-68.

142. Gairola S, Sharma J, Semwal DP, Bahuguna YM. Medicinal plants used for treatment of hepatic disorders by indigenous communities of Jammu and Kashmir, India. Med Plants. 2014;6:413-46.

143. Mayer M, Vogl CR, Amorena M, Hamburger M, Walkenhorst M. Treatment of organic livestock with medicinal plants: a systematic review of European ethnoveterinary research. Forsch Komplementmed. 2014;21:375-86.

144. Govind P. Medicinal plants against liver diseases. Pandey Govind IRJP. 2011; 2:115-21.

145. Ali M, Khan T, Fatima K, Ali QUA, Ovais M, Khalil AT, et al. Selected Hepatoprotective herbal medicines: evidence from ethnomedicinal applications, animal models, and possible mechanism of actions. Phytother Res. 2017. https://doi.org/10.1002/ptr.5957.

146. Shah NA, Khan MR, Nigussie D. Phytochemical, antioxidant and antiLeishmania activity of selected Pakistani plants. Pharmacol Clin Res. 2016;1:2-5.

147. Ngarivhumea T, Klooster $\mathrm{Cl}$, de Jong JT, van der Westhuizen JH. Medicinal plants used by traditional healers for the treatment of malaria in the Chipinge District in Zimbabwe. J Ethnopharmacol. 2015;159:224-37.

148. Pani M, Nahak G, Sahu RK. Review on ethnomedicinal plants of Odisha for the treatment of malaria. Int J Pharmacogn Phytochem Res. 2015;7:156-65.

149. Maroyi A, Cheikhyoussef A. A comparative study of medicinal plants used in rural areas of Namibia and Zimbabwe. Indian J Tradit Knowl. 2015;14:401-6.

150. Adachukwu IP, Yusuf ON. A review of the ethnotherapeutics of medicinal plants used in traditional/alternative medicinal practice in eastern Nigeria. Int J Curr Microbiol App Sci. 2014;3:675-83.

151. Padal SB, Roja NM, Soundarya SD. A review on ethnomedicinal plants used for antidiabetic medicine in Andhra Pradesh. Adv Biol Biomed. 2015:2:1-7.

152. Chen SL, Yu H, Luo HM, Wu Q, Li CF, Steinmetz A. Conservation and sustainable use of medicinal plants: problems, progress, and prospects. Chin Med. 2016;11:37.

153. Das M, Jain V, Malhotra SK. Impact of climate change on medicinal and aromatic plants: review. Indian J Agric Sci. 2016;86:1375-82.

154. Mudie K, Seifu D, Challa F, Abebe A, Debella A, Gebregzabher A Hepatoprotective activity of aqueous seed extract of Nigella sativa against highly active antiretroviral therapy induced hepatotoxicity in rats. PhOL. 2014;3:11-21.

155. Mukazayirea MJ, Allaeys V, Calderonc PB, Stevigny C, Bigendakob MJ, Dueza $P$. Evaluation of the hepatotoxic and hepatoprotective effect of Rwandese herbal drugs on In Vivo (Guinea pigs barbiturate-induced sleeping time) and In Vitro (rat precision-cut liver slices, PCLS) models. Exp Toxicol Pathol. 2010; 62:289-99.

156. Washe AP, Fanta D. Hepatoprotective activities and bioactive constituents of Stephania abyssinica. BJPR. 2016;10:6.

157. Hamzah RU, Jigam AA, Makun HA, Egwim EC. Antioxidant properties of selected African vegetables, fruits and mushrooms: a review. In: Makun HA, editor. Mycotoxin and food safety in developing countries conditions. Nigeria: InTeck; 2013. p. 203-46. https://doi.org/10.5772/52771.

158. Lere D, Washe AP, Alemu F. Determination of antimicrobial and antioxidant activities of extracts from selected medicinal plants. ASRJETS. 2016;16:212-22.

159. Chatoui K, Talbaoui A, Aneb M, Bakri Y, Harhar H, Tabyaoui M. Phytochemical screening, antioxidant and antibacterial activity of Lepidium sativum seeds from Morocco. J Mater Environ Sci. 2016;7:2938-46.
160. Amabye TG. Natural products Chemistry \& Research Evaluation of phytochemical, chemical composition, antioxidant and antimicrobial screening parameters of Rhamnus prinoides (Gesho) available in the market of Mekelle, Tigray, Ethiopia. Nat Prod Chem Res. 2015;4:1.

161. Woldemariam M, Veeresham C, Asres K. Antiinflammatory and Antinociceptive activities of extracts and Syringin isolated from Carduus schimperi Sch. Bip ex A Rich. Phytopharmacology. 2012;3:252-62.

162. Mulisa E, Asres K, Engidawork E. Evaluation of Wound Healing and Antiinflammatory Activity of the Rhizomes of Rumex abyssinicus J. (Polygonaceae) in Mice. BMC Complement Altern Med. 2015;15:342.

163. Adedapo AA, Aremu OJ, Oyagbemi AA. Antioxidant, anti-inflammatory, and antinociceptive properties of the acetone leaf extract of Vernonia amygdalina in some laboratory animals. Adv Pharm Bull. 2014;4:591-8.

\section{Publisher's Note}

Springer Nature remains neutral with regard to jurisdictional claims in published maps and institutional affiliations.

\section{Submit your manuscript to a SpringerOpen ${ }^{\circ}$ journal and benefit from:}

- Convenient online submission

- Rigorous peer review

- Open access: articles freely available online

- High visibility within the field

- Retaining the copyright to your article

Submit your next manuscript at $>$ springeropen.com 